\title{
Cloudiness and Breast Cancer
}

\author{
Ivanka Stajner \\ Noblis, 3150 Fairview Park Drive South, Falls Church, Virginia
}

\begin{abstract}
Traditional risk factors for breast cancer explain only a fraction of cases. Causes for trends in breast cancer incidence are not fully understood. Breast cancer incidence and mortality rates decrease with environmental conditions that promote Vitamin D synthesis in human skin including lower latitude and higher personal exposure to sunlight. Association of temporal variability in breast cancer incidence with changes in cloudiness, which decrease human Vitamin D synthesis is investigated. Association between temporal changes in breast cancer incidence and in the autumn cloudiness for preceding years is computed using data for the United States. There is a correlation of 0.96 (95\% CI $=0.92-1)$ between the time series of breast cancer incidence in the age group of 70-79 years and the average cloudiness in October during preceding 20 years. An empirical model for breast cancer incidence using autumn cloudiness in preceding years captures a rapid increase in breast cancer incidence in the 1980s and some of its yearto-year variability. Increased autumn cloudiness is associated with increased subsequent breast cancer incidence. Proposed mechanism includes blocking of solar ultraviolet radiation by thick clouds and decreasing the synthesis of Vitamin D in human skin. The findings suggest a new connection between climate variability and human health.
\end{abstract}

Keywords: Breast neoplasms; Climate; Incidence; SEER Program; Ultraviolet rays; United States; Vitamin D

Abbreviations: HRT: Hormone Replacement Therapy; EPRT: Estrogen-plus-Progestin Replacement Therapy; ER+: Estrogen Receptor positive; ISCCP: International Satellite Cloud Climatology Project; SEER: Surveillance, Epidemiology and End Results; US: United States; UV: Ultraviolet; WMO: World Meteorological Organization

\section{Introudction}

Breast cancer incidence rates for several representative US regions have been recorded by the Surveillance, Epidemiology, and End Results (SEER) Program of the National Cancer Institute (SEER, 2007) since 1973. Time series of age-adjusted incidence rates $f_{1}(t), f_{2}(t), \ldots, f_{5}(t)$ for five age groups of women are shown in Figure 1. The incidence rates for women diagnosed between 70 and 79 years of age $\left(f_{4}(t)\right.$ : magenta curve) climbed rapidly from mid 1970s to mid 1980s and declined from 1999 to 2004. The introduction of screening mammography, which allows earlier detection of cancer, contributed to the former increase (Miller et al., 1993), but it cannot account for the entire observed increase (White et al., 1990). A decline in the use of hormone replacement therapy (HRT) (Glass et al., 2007) or saturation in screening mammography (Li and Darling, 2007) may have contributed to the latter decline in cancer incidence. Age, early menarche, nulliparity, late age of first full-term pregnancy, late age and short length of lactation, late menopause, genetic mutations, use of HRT, radiation exposure, alcohol consumption, higher educational level and higher socioeconomic status are among risk factors for breast cancer, many of which are related to cumulative exposure to estrogens (Coyle, 2004). However, causes for trends and year-to-year variations in breast cancer incidence are not fully understood (Garfinkel, 1993; Ghafoor et al., 2003).

Low vitamin D status is a risk factor for the development of breast cancer (Coyle, 2004; John et al., 1999). Synthesis in the skin exposed to solar UV radiation is a major source of Vitamin D in humans (Holick, 2004). Breast cancer incidence and mortality are higher in geographic regions with lower UV radiation (Gorham et al., 1990; Garland et al., 1990; Grant, 2002; Grant and Garland, 2006). In the extratropics low wintertime UV amounts may be

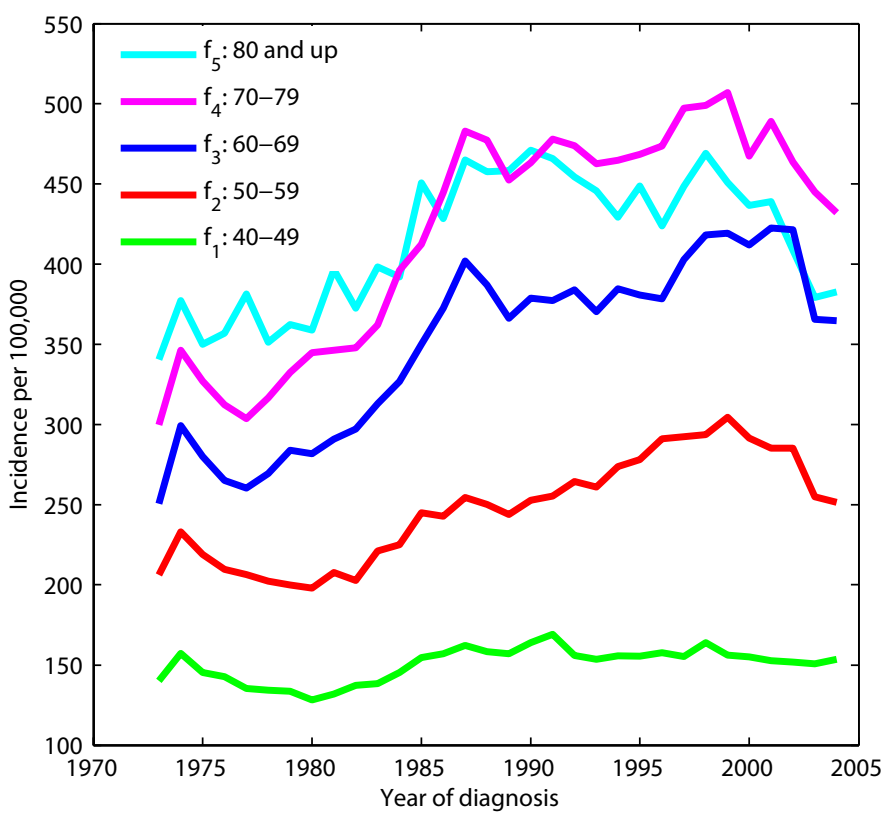

Figure 1: Breast cancer incidence. Annual rates per 100,000 females of any race are shown by the age at diagnosis: $f_{1}$ (age 40-49 years), $f_{2}$ (age 5059), $f_{3}$ (age 60-69), $f_{4}$ (age 70-79) and $f_{5}$ (age 80 and above). Age adjusted incidence rates to standard US population in year 2000 are shown (SEER, 2007). Statistics were generated from malignant cases only.

*Corresponding author: Ivanka Stajner, Noblis, 3150 Fairview Park Drive South, Falls Church, Virginia, Tel: 703-610-2495; Fax: 703-6101767; E-mail: Ivanka.Stajner@noblis.org

Received October 29, 2009; Accepted November 26, 2009; Published November 26, 2009

Citation: Stajner I (2009) Cloudiness and Breast Cancer. J Cancer Sci Ther 1: 034-040. doi:10.4172/1948-5956.1000006

Copyright: () 2009 Stajner I, et al. This is an open-access article distributed under the terms of the Creative Commons Attribution $\mathrm{Li}$ cense, which permits unrestricted use, distribution, and reproduction in any medium, provided the original author and source are credited. 
inadequate for vitamin D synthesis (Webb et al., 1988) causing seasonal variability in serum Vitamin D status (Lappe et al., 2006; Kull et al., 2009). Due to Vitamin D half-life of 1-2 months (Vieth, 1999), a deficiency is common at the end of the winter (Holick, 2004). Assuming that autumn vitamin D synthesis modulates subsequent Vitamin D minima (Figure 2), we ask: Is interannual variability in the autumn surface UV radiation related to breast cancer incidence?

High quality, multi-decadal observations of surface UV are needed to examine temporal association between UV radiation and breast cancer incidence. However, ground-based observations providing time series since 1960s are of insufficient quality to establish trends (Weatherhead et al., 1997). A newer network of ground based stations has been collecting UVB observations since 1990s (Bigelow et al., 1998), but their record is too short at the time of this writing. Assuming that exposure is relevant over about two decades from initiation to detection of breast cancer, about 50 years of UV data are needed to evaluate association with the 30 years of subsequent SEER breast cancer incidence rates. Satellite estimates of surface UV have difficulties over polluted sites (McKenzie et al., 2001), where they do not capture reduction in UV radiation caused by urban aerosols near the ground (Herman et al., 1999). Solar UV radiation is scattered and absorbed in the atmosphere by clouds, ozone, aerosols, and nitrogen dioxide (WMO, 2003). Thick clouds can reduce UV-B radiation at wavelengths of $290-320 \mathrm{~nm}$ by $80 \%$ (Frederick and Steele, 1995). The focus of this study is on interannual variability in cloudiness due to its large impact on surface UV.

\section{Materials and Methods}

For 1987 and earlier years we use monthly mean daylight cloud amounts from an edited record of all US ground stations (Karl and Steurer, 1990), which was used to study cloudiness trends over the United States. Due to changes in observing practices spurious trends may exist between late 1930s and late 1940s. An increasing trend in cloudiness and a consistent decrease in

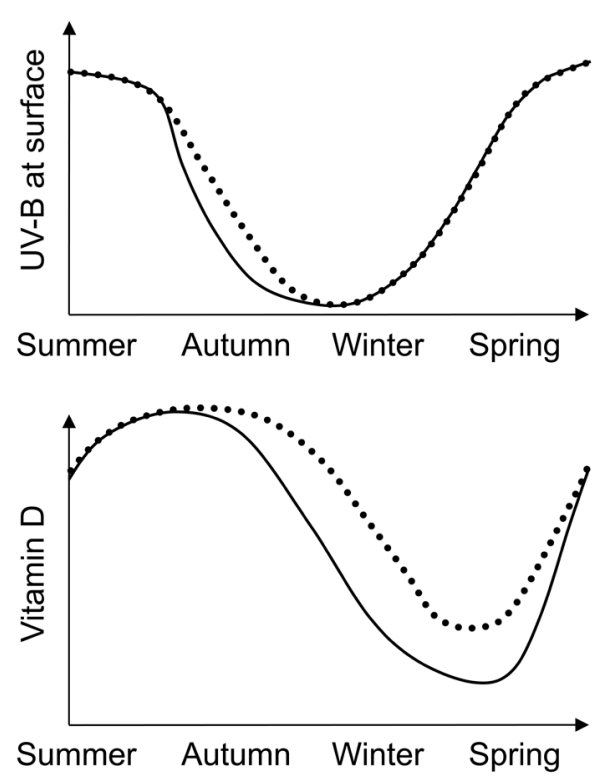

Figure 2: Schematic annual cycle. Idealized annual cycle is shown for a) UV-B at the surface for cloud-free conditions (dotted) and for cloudy autumn (solid) and for b) corresponding serum 25-hydroxyvitamin D [25(OH)D] concentration.

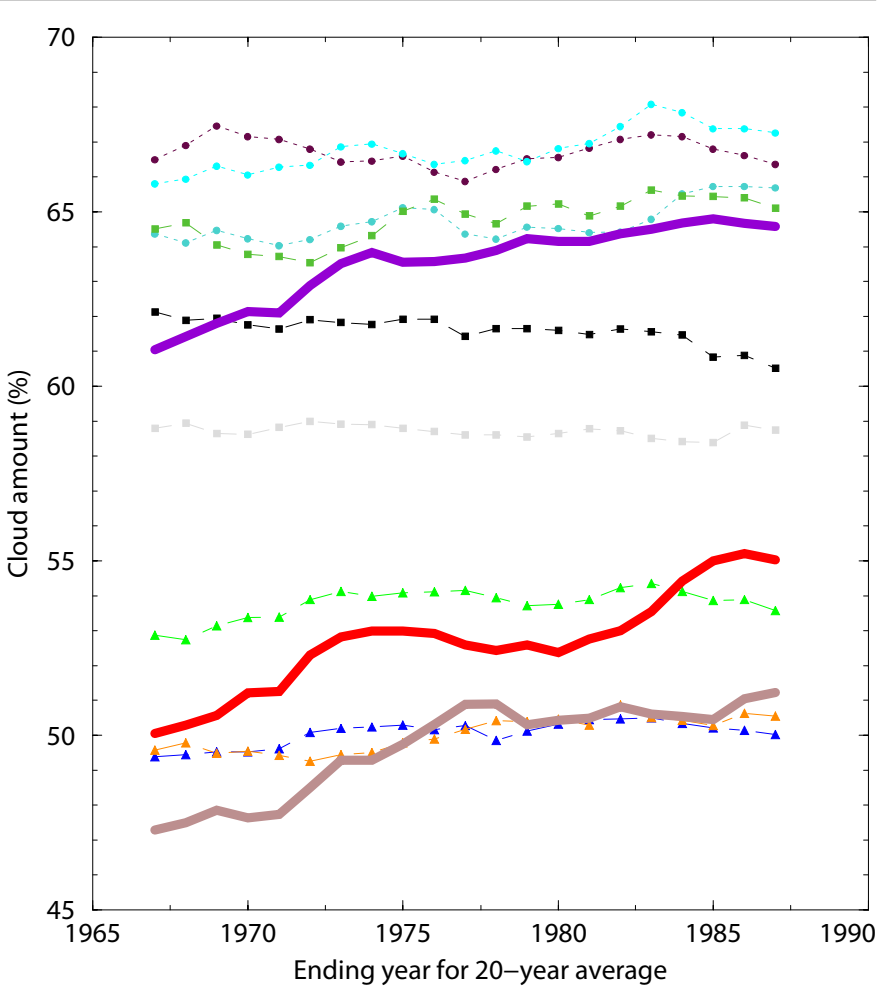

Figure 3: Average cloudiness for each month for the preceding 20 years. Months are marked by season: winter (circles), spring (squares) and summer (triangles). Autumn months are shown by thicker lines: September (brown), October (red) and November (violet).

temperature range were found since 1948. From each of the nine SEER regions we selected one ground station with complete records from 1948 to 1987. Two stations are available in Iowa; Sioux City is very close to the state border, so Des Moines was selected to represent this state. Only one station has a complete record in each of the other four SEER states: Hartford in Connecticut, Albuquerque in New Mexico, Salt Lake City in Utah, and Honolulu in Hawaii. For each of the four SEER metropolitan areas (San Francisco, California; Seattle, Washington; Detroit, Michigan; and Atlanta, Georgia) there is a ground station for that metropolitan area.

Variability in cloudiness over several years is examined using the spatial average over the nine stations in SEER regions. For each month this cloudiness was averaged for 20-year intervals. From the 20-year interval ending in 1967 to the 20-year interval ending in 1987 the largest increase in cloudiness is seen for October (5\%), followed by September (4\%), and November (3.5\%, Figure 3). Due to this substantial increase in cloudiness in the autumn months, we focus the remaining analysis on the autumn months.

Monthly cloudiness records for the nine stations in SEER regions were extended to year 2004 using monthly total cloud amounts from satellite based International Satellite Cloud Climatology Project (ISCCP) data (Rossow and Schiffer, 1999). Measurements from geostationary and polar orbiting satellites are combined every 3 hours and subsequently averaged to produce ISCCP monthly total cloud amounts. Multiple satellites provide measurements over some locations. Thus, ISCCP uses a hierarchy of preferred sources of satellite data that based on satellite observing geometries, with preference for data from the satellite 


\section{Journal of Cancer Science \& Therapy - Open Access \\ www.omicsonline.org \\ JCST/Vol.1 Issue 1}

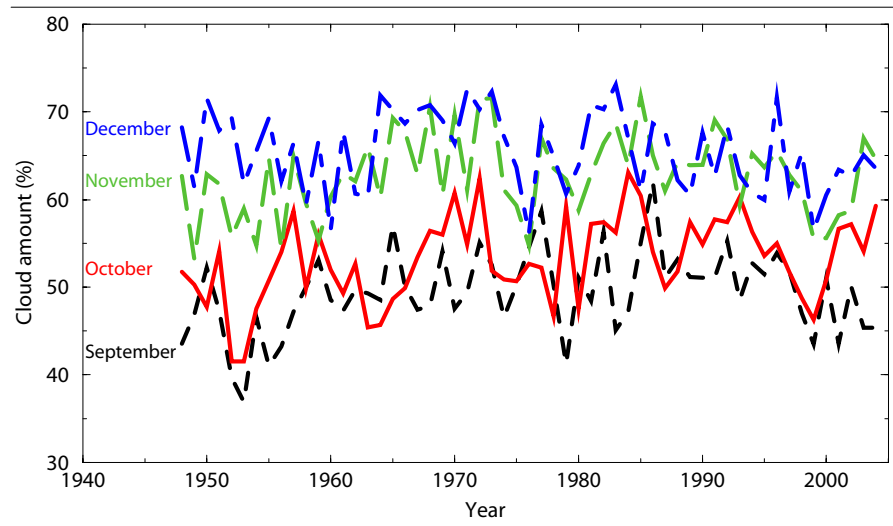

Figure 4: Monthly average cloudiness. Average cloud amounts for the nine ground stations in SEER regions are shown for September $\left(g_{g}\right.$ : black), October $\left(g_{10}:\right.$ red $)$, November $\left(g_{11}:\right.$ green $)$ and December $\left(g_{12}:\right.$ blue $)$.

closest to being overhead rather than low on the horizon. For the 48 contiguous United States and Hawaii the primary data sources are geostationary satellites (Geostationary Operational Environmental Satellite (GOES)-East and GOES-West). The monthly maps of cloudiness from ISCCP allow us to examine how well cloudiness over chosen stations represents cloudiness over SEER regions. For example, the October cloudiness from 1983 to 2004 over Des Moines and the cloudiness over a rectangular area representing Iowa both vary from $<60 \%$ to $>75 \%$; even though cloudiness for Des Moines is $1.8 \%$ lower, there is a correlation of 0.95 between their time series. Differences between ground-based and satellite observations during the 19801987 overlap period are typically smaller than the interannual variability in the records at each of the nine stations. Figure 4 shows the time series of the nine-station average of the cloud amounts for September, October, November, and December, which are denoted by $g_{9}, g_{10}, g_{11}$, and $g_{12}$, respectively.

In order to examine the relationship between multi-annual averages of cloudiness in one of the autumn months and the breast cancer incidence, we formulate the following model $h$ to compare with breast cancer incidence $f_{i}$ :

$$
h(t)=c+\frac{b}{l} \sum_{k=a}^{a+l-1} g_{j}(t-k), \text { for } j=9,10,11,12 .
$$

In this model monthly cloud amounts $g_{j}$ are averaged over $l$ years, with a lag of $a$ years. In order to match ranges of $f_{i}$ and $h$, linear stretching is controlled by parameter $b$ and offsets by $c$.
For example, for $j=10, g_{j}$ is cloudiness for October. Cloudiness is averaged over several $(l)$ years because cancer may be influenced by conditions that occurred over decades before its detection. The lag parameter $a$ is introduced to allow a possibility that cloudiness in the last few years may be irrelevant, e.g. if the cancer is too advanced to be influenced by saddle changes in Vitamin D sources. All cloudiness attains values between 0 (clear sky) and 100 (cloud covered sky), so by construction, averages of cloudiness will produce numbers between 0 and 100. In order to fit breast cancer incidence (which e.g. varies from $\sim 300 / 100,000$ to $\sim 500 / 100,00$ for women in the age group 70-79 as seen in Figure 1) parameter $b$ allows adjusting the range of variability, and the parameter $c$ allows vertical offsets to bring curves closer together.

Using least-squares norm we determine the best fit $h_{i}(t)$ to $f_{i}(t)$, for $i=1,2, \ldots, 5, j=9,10,11,12, a \geq 0, l \geq 1$ and $a+l \leq 25$. The causality limits $a$ to be positive. Total temporal shifts $(a+l)$ do not exceed 25 years to avoid artificial offsets in cloudiness data in 1930 s and 1940s caused by changes in cloud measurement techniques (Karl and Steurer, 1990).

\section{Results}

For the age group 70-79 the best least-squares fit to $f_{4}$ is provided by $h_{4}$ using cloudiness in October $(j=10)$ and the following parameters:

$$
a=1, l=20, b=58.78 \text {, and } c=-2764.9 \text {. }
$$

Thus, the best fit uses October cloudiness for 1 to 20 ( $a$ to $a+l$ 1) years before the cancer incidence. Note the importance of parameter $b$ : it quantifies the increase of cancer incidence rate per 100,000 individuals corresponding to a $1 \%$ increase in the average cloudiness over the $l$ years in the model $h$. Cloudiness for October or November provided best fit for all five age groups, with the parameters in Table 1. The correlation coefficients between the incidence and best fit models range from 0.84 $(95 \% \mathrm{CI}=0.70-0.95)$ to $0.96(95 \% \mathrm{CI}=0.92-1)$. The time series of best fit models in Figure 5 capture the strong increases in breast cancer incidence rates during 1980 s and more stable rates since 1987.

Spatial association between cloudiness and breast cancer was investigated as well. There is a correlation of 0.815 between $20-$ year average (1983-2002) of October cloudiness (Rossow and Schiffer, 1999) over regions included in the SEER program and the breast cancer incidence in 2003 for white women older than

\begin{tabular}{|l|l|l|l|l|l|l|l|l|}
\hline $\begin{array}{l}\text { Age } \\
\text { group }\end{array}$ & $\begin{array}{l}\text { Group } \\
\text { index } \\
\boldsymbol{i}\end{array}$ & $\begin{array}{l}\text { Month } \\
\boldsymbol{j}\end{array}$ & $\begin{array}{l}\text { Number } \\
\text { of years } \\
\boldsymbol{l}\end{array}$ & $\begin{array}{l}\text { Lag } \\
\boldsymbol{a}\end{array}$ & $\begin{array}{l}\text { Sensitivity } \\
\text { to change In } \\
\text { Cloudiness } \\
\boldsymbol{b}\end{array}$ & $\begin{array}{l}\text { Offset } \\
\boldsymbol{c}\end{array}$ & $\begin{array}{l}\text { Correlation } \\
\text { between } \\
\boldsymbol{f}_{\boldsymbol{i}} \text { and } \boldsymbol{h}_{\boldsymbol{i}}\end{array}$ & $\begin{array}{l}\text { 95\% } \\
\text { confidence } \\
\text { interval }\end{array}$ \\
\hline $\mathbf{4 0 - 4 9}$ & 1 & 10 & 19 & 1 & 7.9513 & -280.8 & 0.8408 & $0.6962-0.9537$ \\
\hline $\mathbf{5 0 - 5 9}$ & 2 & 10 & 17 & 2 & 26.3441 & -1182.2 & 0.9342 & $0.8684-0.9924$ \\
\hline $\mathbf{6 0 - 6 9}$ & 3 & 10 & 20 & 1 & 46.3609 & -2151.3 & 0.9483 & $0.8958-0.9953$ \\
\hline $\mathbf{7 0 - 7 9}$ & 4 & 10 & 20 & 1 & 58.7847 & -2764.9 & 0.9599 & $0.9187-0.9972$ \\
\hline $\mathbf{8 0 +}$ & 5 & 11 & 23 & 2 & 47.8014 & -2636.2 & 0.8704 & $0.7490-0.9698$ \\
\hline
\end{tabular}

Table 1: The parameters for model $h_{i}$ that provide best fit using least square norm to the breast cancer incidence $f_{i}$ for five age groups. 


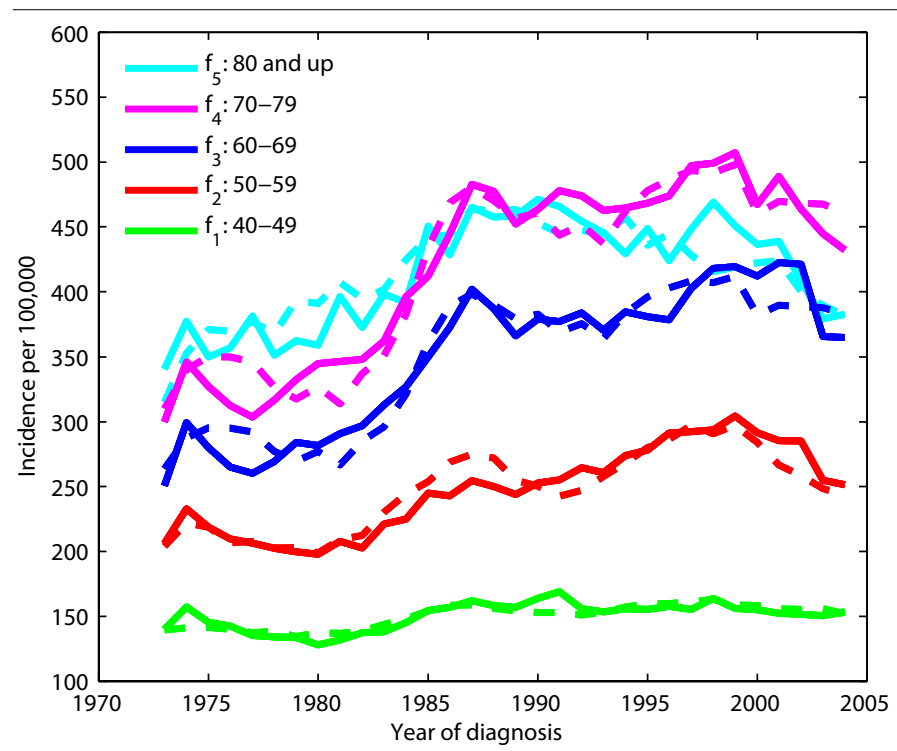

Figure 5: Empirical model using best fit parameters. Breast cancer incidence $f_{1}$ to $f_{5}$ for women of ages 40-49, 50-59, 60-69, 70-79, 80 and older (solid: colors as in Figure 1) and the fit functions $h_{1}$ to $h_{5}$ (dashed) with parameters given in Table 1.

65 years (Table 2). Note that solar zenith angle, cloudiness and ozone, which all decrease surface UV-B, typically increase with increasing latitude, so the correlation is not likely to be due to changes in cloudiness alone. Latitude of SEER cities and geographic centers for SEER states is also given in Table 2. There is a negative correlation of -0.366 between latitude and breast cancer incidence rates, indicating that latitude alone does not explain variability in breast cancer incidence rates. The surprising negative correlation is due to Hawaii data. When correlations are computed for 8 SEER regions, excluding Hawaii, there is a positive correlation of 0.564 between latitude and breast cancer incidence. Correlation between cloudiness and breast cancer is much less sensitive to exclusion of Hawaii data; it drops only slightly to 0.813 .

\section{Discussion}

High temporal correlations between autumn cloudiness and breast cancer incidence exist, which do not imply causality. However, we assert that synthesis of Vitamin D in human skin is the linking mechanism, which is consistent with earlier studies of environmental exposure to solar radiation (John et al., 1999;
Gorham et al., 1990; Garland et al., 1990; Grant, 2002). Dietary supplementation provides an alternative source of Vitamin D and another mode of intervention in order to reduce the burden of breast cancer. Randomized trials of daily Vitamin D and calcium supplementation in postmenopausal women showed mixed results: $400 \mathrm{IU}$ of Vitamin D and $1000 \mathrm{mg}$ of elemental calcium did not reduce colon cancer incidence (Wactawski-Wende et al., 2006), but $1100 \mathrm{IU}$ of Vitamin D plus 1400-1500 mg of calcium substantially reduced incidence of breast, colon, and several other cancers (Lappe et al., 2007). The latter trial, which is consistent with our findings, had a smaller sample population, but its strengths lie in the higher dose of Vitamin D and a better adherence to treatment.

This is the first study into factors influencing autumn synthesis of Vitamin D and subsequent cancer incidence. Several factors modulating surface UV radiation in the autumn may be important. This study focuses on the large variability caused by clouds. Spatial correlation of 0.815 was found between autumn cloudiness and subsequent breast cancer incidence, which is much stronger than the spatial correlation that was found between latitude and breast cancer incidence. Correlations between breast cancer incidence and annual mean of the total solar radiation (-0.75, Gorham et al., 1990) are weaker. Correlations between breast cancer mortality and annual mean of the total solar radiation (-0.80, Garland et al., 1990) or summertime UV radiation (0.67 , Grant, 2002) are weaker as well. Wintertime UV radiation may be inadequate for synthesis of Vitamin D (Webb et al., 1988), making autumn the key period for synthesis of Vitamin D that is used during winter. In contrast, cloudiness in the spring is not expected to have a lasting effect because UV radiation is generally increasing during this season.

High temporal correlations of up to 0.96 were found between cloudiness in the autumn months, especially October, and subsequent breast cancer incidence. This temporal correlation is stronger than any of the previously discussed spatial correlations. Variability in cloudiness is a major factor causing interannual variability in UV radiation at the surface. Other factors include variability in ozone, aerosols or nitrogen dioxide (WMO, 2003). Interannual ozone variability in the northern middle latitudes is the lowest in the autumn (September to November) among all the seasons (WMO, 2003). Changes in atmospheric aerosol concentrations may have caused a $5 \%$ decline in the solar radiation

\begin{tabular}{|l|l|l|l|l|l|l|l|l|l|}
\hline & $\begin{array}{l}\text { New } \\
\text { Mexico }\end{array}$ & Utah & Atlanta & Connecticut & Seattle & Detroit & Iowa & $\begin{array}{l}\text { San } \\
\text { Francisco }\end{array}$ & Hawaii \\
\hline $\begin{array}{l}\text { Cloudiness } \\
\text { in October } \\
\mathbf{1 9 8 3 - 2 0 0 2} \\
{[\%]}\end{array}$ & 38.8 & 42.65 & 50.55 & 56.425 & 59.925 & 60.875 & 61 & 64.075 & 66.225 \\
\hline $\begin{array}{l}\text { Latitude } \\
\text { [degres N] }\end{array}$ & 34.50 & 39.38 & 33.65 & 41.60 & 47.45 & 42.42 & 41.96 & 37.62 & 20.95 \\
\hline $\begin{array}{l}\text { Breast cancer } \\
\text { incidence rate } \\
\text { per 100,000 } \\
\text { for 65+ }\end{array}$ & 368.4 & 374.4 & 413.2 & 419.7 & 490.5 & 430.4 & 409.2 & 472.4 & 542.5 \\
\hline
\end{tabular}

Table 2: Average cloudiness, latitude (of geographic center for states), and breast cancer incidence for white females older than 65 years in 9 SEER regions. 


\section{Journal of Cancer Science \& Therapy - Open Access}

\section{www.omicsonline.org}

incident at the Earth's surface from 1960 to 1990 and a later increase through 1990s (Wild et al., 2005). Aerosol variability could also be related to breast cancer incidence, and is a topic for future research.

Stratification of cloudiness-cancer correlations by age group or time period provides insight into possible roles of Vitamin D. First, among all age groups correlations are the highest for ages 70-79, when occurrence of estrogen receptor positive (ER+) breast cancer peaks (Anderson and Matsuno, 2006). Given that temporal variability of less common estrogen receptor negative cancer differs (Glass et al., 2007) from that of ER+, this suggests a stronger link between cloudiness and ER+ breast cancer. Second, restricting the analysis to periods receding widespread estrogen-plusprogestin replacement therapy (EPRT), the highest correlation of 0.972 is found between 1973-1988 breast cancer incidence for ages 70-79 and cloudiness for 12 Decembers at least 13 years before the cancer detection. This suggests a preventative role of vitamin $\mathrm{D}$ in initial phases of cancerogenesis. Third, inclusion of data for 1990s shifts best fit to October cloudiness. Estrogen therapy alone raises levels of the highly active 1,25-dihydroxyvitamin $\mathrm{D}$, but the addition on progestin lowers its levels (Bikkle et al., 1992). Vitamin D requirements might increase during EPRT shifting the sensitivity to October cloudiness, when UV radiation is stronger, and to the years closer to the cancer detection, when vitamin D may play a role in suppressing the growth of still undetected cancer that is fueled by the EPRT (Dietel et al., 2005).

Since the release of Women's Health Initiative trial results, the use of EPRT has declined substantially. Ravdin et al., (2007) attributed the subsequent reduction of breast cancer incidence rates to the decline in the use of EPRT. However, it is plausible that vitamin D supplementation increased concurrently and also contributed to the reduction of breast cancer incidence rates. Such increase in vitamin D supplementation would be consistent with recent trends that show almost five-fold increase in vitamin D prescriptions from year 2006 to year 2008 (Drug Topics, 2009). Additional data are needed on recent trends in serum vitamin D levels. Note that a marked decrease in serum $25(\mathrm{OH}) \mathrm{D}$ levels was observed from the 1988-1994 to the 2001-2004 National Health and Nutrition Examination Survey (NHANES) data collections (Ginde et al., 2009).

It is recognized that factors other than ambient UV light exposure, such as personal behavior, melanin content, and age, have impact on Vitamin D synthesis and Vitamin D status (Holick, 2004; McCarty, 2008). Avoidance of UV radiation in order to decrease risk of skin cancer is common and it may be leading to Vitamin D deficiency. For example, sunscreen efficiency and use have increased. Under very controlled conditions the sunscreen can completely suppress cutaneous Vitamin D synthesis. However, when subjects were allowed to apply their own sunscreen no significant changes in serum concentrations of Vitamin D were found (McCarty, 2008). A limitation of the present study is that associations were observed in groups and may not apply to individuals within these groups. Thus, further study of individual exposure, serum vitamin $\mathrm{D}$ levels and breast cancer risk is needed. Higher personal exposure to sunlight determined by physician assessment or self-reported frequent recreational or occupational exposure were shown to lower breast cancer risk (John et al., 1999). Analysis of personal skin pigmentation mea-

\section{JCST/Vol.1 Issue 1}

surements showed a reduced risk of advanced breast cancer among women with naturally light skin pigmentation and higher pigmentation on the forehead, which indicates higher exposure to sunlight (John et al., 2007). Furthermore, several recent casecontrol studies found an inverse association between serum vitamin D levels and breast cancer risk (Blackmore et al., 2008; Abbas et al., 2008; Crew et al., 2009; Rossi et al., 2009). A future study that takes measurements of Vitamin D status at the end of the winter following varying autumn cloudiness over several years could provide further information about the asserted connection among cloudiness and Vitamin D status, and potential links to breast cancer incidence.

High temporal correlations between autumn cloudiness and subsequent breast cancer incidence offer an alternative to previously proposed explanations of breast cancer trends (Miller et al., 1993; White et al., 1990; Glass et al., 2007; Li and Darling, 2007; Garfinkel, 1993; Ghafoor et al., 2003). The length of breast cancer incidence time series is a limitation of the study. Its strengths lie in the use of independently collected datasets, focus on the autumn season, and on cloudiness as a major modulator of the solar UV reaching the Earth's surface. The proposed mechanism of action through modulation of Vitamin D synthesis in human skin provides a new example of possible interaction between climate variability and human health on decadal scales.

\section{Acknowledgment}

This study was supported by the internal research and development program of the Science Applications International Corporation.

\section{References}

1. Abbas S, Linseisen J, Slanger T, Kropp S, Mutschelknauss EJ, et al. (2008) Serum 25-hydroxyvitamin D and risk of post-menopausal breast cancer-results of a large case-control study. Carcinogenesis 29: $93-$ 99. » CrossRef » PubMed » Google Scholar

2. Anderson WF, Matsuno R (2006) Breast cancer heterogeneity: a mixture of at least two main types. J Natl Cancer Inst 98: 948-51. »CrossRef »PubMed » Google Scholar

3. Bigelow DS, Slusser JR, Beaubien AF, Gibson JH (1998) The USDA Ultraviolet Radiation Monitoring Program. Bull Amer Meteorol Soc 79: 601-615. »CrossRef » Google Scholar

4. Bikle DD, Halloran BP, Harris ST, Portale AA (1992) Progestin antagonism of estrogen stimulated 1,25-dihydroxyvitamin D levels. J Clin Endocrinol Metab 75: 519-23. »CrossRef » PubMed » Google Scholar

5. Blackmore KM, Lesosky M, Barnett H, Raboud JM, Vieth R, et al. (2008) Vitamin D From Dietary Intake and Sunlight Exposure and the Risk of Hormone-Receptor-Defined Breast Cancer. Am J Epidemiol 168: 915-924. »CrossRef » PubMed » Google Scholar

6. Coyle YM (2004) The effect of environment on breast cancer risk. Breast Cancer Res Treat 84: 273-288. » CrossRef » PubMed » Google Scholar

7. Crew KD, Gammon MD, Steck SE, Hershman DL, Cremers S, et al. (2009) Association between plasma 25-hydroxyvitamin D and breast cancer risk. Cancer Prev Res 2: 598-604. » CrossRef » PubMed » Google Scholar

8. Dietel M, Lewis MA, Shapiro S (2005) Hormone replacement therapy: pathobiological aspects of hormone-sensitive cancers in women relevant to epidemiological studies on HRT: a mini-review. Hum Reprod 20: 2052-60. »CrossRef » PubMed » Google Scholar

9. Drug Topics (2009) Drugs by units in the United States in specific years.

10. Frederick JE, Steele HD (1995) The transmission of sunlight through 
cloudy skies: An analysis based on standard meteorological information. J Appl Meteorol 34: 2755-2761. » CrossRef » Google Scholar

11. Garfinkel L (1993) Current trends in breast cancer. CA Cancer J Clin 43: 5-6. » CrossRef » PubMed » Google Scholar

12. Garland FC, Garland CF, Gorham ED, Young JF (1990) Geographic variation in breast cancer mortality in the United States: a hypothesis involving exposure to solar radiation. Prev Med 19: 614-622. » PubMed $»$ Google Scholar

13. Ghafoor A, Jemal A, Ward E,Cokkinides V, Smith R, et al. (2003) Trends in Breast Cancer by Race and Ethnicity. CA Cancer J Clin 53: 342-355. » CrossRef » PubMed » Google Scholar

14. Ginde AA, Liu MC, Camargo CA Jr (2009) Demographic Differences and Trends of Vitamin D Insufficiency in the US Population, 19882004. Arch Intern Med 169: 626-632. » CrossRef » PubMed » Google Scholar

15. Glass AG, Lacey JV Jr, Carreon JD, Hoover RN (2007) Breast cancer incidence, 1980-2006: combined roles of menopausal hormone therapy, screening mammography, and estrogen receptor status. J Natl Cancer Inst 99: 1152-61. » CrossRef » PubMed » Google Scholar

16. Gorham ED, Garland FC, Garland CF (1990) Sunlight and breast cancer incidence in the USSR. Int J Epidemiol 19: 820-824. » CrossRef » PubMed » Google Scholar

17. Grant WB (2002) An estimate of premature cancer mortality in the U.S. due to inadequate doses of solar ultraviolet-B radiation. Cancer 94: 1867-75. »CrossRef » PubMed » Google Scholar

18. Grant WB, Garland CF (2006) The association of solar ultraviolet B (UVB) with reducing risk of cancer: multifactorial ecologic analysis of geographic variation in age-adjusted cancer mortality rates. Anticancer Res 26: 2687-99. » CrossRef » PubMed » Google Scholar

19. Herman JR, Krotkov N, Celarier E, Larko D, Labow G (1999) Distribution of UV radiation at the Earth's surface from TOMS-measured UV-backscattered radiances. J Geophys Res 104: 12059-12076. » CrossRef » Google Scholar

20. Holick MF (2004) Sunlight and vitamin D for bone health and prevention of autoimmune diseases, cancers and cardiovascular disease. Am J Clin Nutr 80: 1678S-88S. » CrossRef » PubMed » Google Scholar

21. John EM, Schwartz GG, Dreon DM, Koo J (1999) Vitamin D and Breast Cancer Risk: The NHANES I Epidemiologic Follow-up Study, 1971-1975 to 1992. Cancer Epidemiology Biomarkers \& Prevention 8: 399-406. » CrossRef » PubMed » Google Scholar

22. John EM, Schwartz GG, Koo J, Wang W, Ingles SA (2007) Sun exposure, vitamin $\mathrm{D}$ receptor gene polymorphisms, and breast cancer risk in a multiethnic population. Am J Epidemiol 166: 1409-19. »CrossRef » PubMed » Google Scholar

23. Karl TR, Steurer PM (1990) Increased cloudiness in the United States during the first half of the twentieth century: Fact or fiction. Geophys Res Lett 17: 1925-1928. » CrossRef » Google Scholar

24. Kull M, Kallikorm R, Tamm A, Lember M (2009) Seasonal variance of 25- $(\mathrm{OH})$ vitamin $\mathrm{D}$ in the general population of Estonia, a Northern European country. BMC Public Health 9: 22. »CrossRef » PubMed » Google Scholar

25. Lappe JM, Davies KM Travers-Gustafson D, Heaney RP (2006) Vitamin D status in a rural postmenopausal female population. J Am Coll Nutr 25: 395-402. » CrossRef » PubMed » Google Scholar

26. Lappe JM, Travers-Gustafson D, Davies KM, Recker RR, Heaney RP (2007) Vitamin D and calcium supplementation reduces cancer risk: results of a randomized trial. Am J Clin Nutr 85: 1586-91. » CrossRef » PubMed » Google Scholar

27. Li CI, Darling JR (2007) Changes in Breast Cancer Incidence Rates in the United States by Histologic Subtype and Race/Ethnicity, 1995 to 2004. Cancer Epidemiol Biomarkers Prev 16: 2773-2780. »CrossRef » PubMed » Google Scholar

28. McCarty CA (2008) Sunlight exposure assessment: can we accurately assess vitamin D exposure from sunlight questionnaires. Am J Clin Nutr 87: 1097S-1101S. »CrossRef » PubMed » Google Scholar

29. McKenzie RL, Seckmeyer G, Bais AF, Kerr JB, Madronich S (2001) Satellite retrievals of erythemal UV dose compared with ground-based measurements at northern and southern midlatitudes. J Geophys Res 106: 24051-24062. » CrossRef » Google Scholar

30. Miller BA, Feuer EJ, Hankey BF (1993) Recent incidence trends for breast cancer in women: An update. CA Cancer J Clin 43: 27-41. »CrossRef » PubMed » Google Scholar

31. Ravdin PM, Cronin KA, Howlader N, Berg CD, Chlebowski RT, et al. (2007) The decrease in breast-cancer incidence in 2003 in the United States. Engl J Med 356: 1670-4. » CrossRef » PubMed » Google Scholar

32. Rossi M, McLaughlin JK, Lagiou P, Bosetti C, Talamini R, et al. (2009) Vitamin D intake and breast cancer risk: a case-control study in Italy. Ann Oncol 20: 374-8. » CrossRef » PubMed » Google Scholar

33. Rossow WB, Schiffer RA (1999) Advances in understanding clouds from ISCCP. Bull of the Amer Meteor Soc 80: 2261-2287. » CrossRef $»$ Google Scholar

34. Surveillance, Epidemiology, and End Results (SEER) Program (www.seer.cancer.gov) SEER*Stat Database: Incidence - SEER 9 Regs Limited-Use, Nov 2006 Sub (1973-2004), National Cancer Institute, DCCPS, Surveillance Research Program, Cancer Statistics Branch, released April 2007, based on the November 2006 submission.

35. Vieth R (1999) Vitamin D supplementation, 25-hydroxyvitamin D concentrations, and safety. Am J Clin Nutr 69: 842-56. » CrossRef » PubMed » Google Scholar

36. Wactawski-Wende J, Kotchen JM, Anderson GL, Assaf AR, Brunner RL, et al. (2006) Calcium plus vitamin D supplementation and the risk of colorectal cancer. N Engl J Med 354: 684-96. ” CrossRef » PubMed » Google Scholar

37. Weatherhead EC, Taio GC, Reinsel GC, Frederick JE, DeLuisi JJ, et al. (1997) Analysis of long-term behavior of ultraviolet radiation measured by Robertson-Berger meters at 14 sites in the United States. J Geophys Res 102: 8737-8754. » CrossRef » Google Scholar

38. Webb AR, Kline L, Holick MF (1988) Influence of season and latitude on the cutaneous synthesis of vitamin D3: exposure to winter sunlight in Boston and Edmonton will not promote vitamin D3 synthesis in human skin. J Clin Endocrinol Metab 67: 373-8. » CrossRef » PubMed $»$ Google Scholar

39. White EW, Lee CY, Kristal AR (1990) Evaluation of the increase in breast cancer incidence in relation to mammography use. J Natl Cancer Inst 82: 1546-1552. »CrossRef » PubMed » Google Scholar

40. Wild M, Gilgen H, Roesch A, Ohmura A, Long CN, et al. (2005) From Dimming to Brightening: Decadal Changes in Solar Radiation at Earth's Surface. Science 308: 847-850. » CrossRef » PubMed » Google Scholar

41. World Meteorological Organization (2003) Scientific assessment of ozone depletion: 2002, in Global Ozone Research and Monitoring Project. 


\section{Journal of Cancer Science \& Therapy - Open Access}

www.omicsonline.org

JCST/Vol.1 Issue 1

\section{OMICS Publishing Group}

\section{List of Journals}

1.Journal of Proteomics \& Bioinformatics (JPB) Open Access

2.Journal of Bioequivalence \& Bioavailability (JBB) Open Access

3.Journal of Computer Science \& Systems Biology (JCSB) Open Access

4.Journal of Antivirals \& Antiretrovirals (JAA) Open Access

5.Journal of Data Mining in Genomics \& Proteomics (JDMGP) Open Access

6.Journal of Glycomics \& Lipidomics (JGL) Open Access

7.Journal of Pharmacogenomics \& Pharmacoproteomics(JPP) Open Access

8.Journal of Postgenomics: Drug \& Biomarker Development (JPDBD) Open Access

9.Journal of Biochips and Tissue Chips (JBTC) Open Access

10.Journal of Molecular Biomarkers \& Diagnosis (JMBD) Open Access

11.Journal of Bioanalysis \& Biomedicine (JBABM) Open Access

12.Journal of Nanomedicine \& Biotherapeutic Discovery (JNBD) Open Access

13.Journal of Cancer Science \& Therapy (JCST) Open Access

14.Journal of Biotechnology \& Biomaterials (JBTBM) Open Access

15.Journal of Petroleum \& Environmental Biotechnology (JPEB) Open Access

16.Journal of Microbial \& Biochemical Technology (JMBT) Open Access

17.Journal of Tissue Sciences \& Engineering (JTSE) Open Access

18.Briefings in Intellectual Property Rights (BIPR) Open Access 